\title{
MOVEMENT AND ENLIGHTENMENT IN THE RUSSIAN NORTH
}

\author{
Eva Toulouze
}

\begin{abstract}
In the process of integrating the Northern areas into the Russian world, both missionaries and Soviet activists have endeavoured to change the local population's minds and worldview, in order to get it in compliance with the new world they were bringing. But the indigenous population was nomadic. This presented a considerable challenge to the enlighteners. How did they cope with it? Did they attempt to become "temporarily" nomads themselves or did they try to compel the people to change also their way of life? Were there differences in strategies between the Christian missionaries of the turn of the 19th and 20th centuries and the Soviet "cultural construction" activists? These are the questions this article attempts to find an answer to.
\end{abstract}

Key words: cultural bases, education, enlightment, nomadic school, nomadism, Orthodox missionaries, sedentarisation, soviet activists, Western Siberia

\section{INTRODUCTION}

In the history of their contacts with aliens, the natives of the Russian North have often met people who wanted something from them (furs, fish) and others who wanted to change something in their lives. Among the latter, some were bearers of what they considered a universal truth - the Christian gospel and the promise of eternal life in the case of the Orthodox (and lately Protestant) missionaries, the Marxist dogma and the promise of earthly communism in the case of the "red" missionaries. As far as nomads - and "primitive peoples" in general - are concerned, this issue was completed by a parallel attempt - either to enlighten or to change them altogether both in their worldview and in their way of life.

But nomadism presents its own peculiar features and difficulties: through movement, nomads are more easily able to escape those who interfere with them than sedentary cultures are. Thus, movement becomes an obstacle for the enlighteners. How did they cope with this challenge? How did they, how do they adapt? Do they become nomads themselves? Do they try to change this custom or do they attempt to fight the mere fact of nomadism? A study of this 
question will allow drawing a comparison between the methods of the two different kinds of ideologists.

Why nomadism is a problem?

1. Nomads are difficult to encounter. As they are permanently on the move, those who seek them can never be sure of where they are located at the moment. Actually, in the beginning of the encounter, even semi-nomads present a challenge, as they are scattered over huge territories, unknown to the "enlighteners". So movement is a challenge, no less so than their general lifestyle and environment. Moreover: if nomadic people wish to avoid meeting someone, they have the means to escape. Even when the encounter has taken place, the nomads are very easily able to flee and pursue their journeys if the contact does not please them.

2. Nomads are difficult to control. The following up of "results" achieved is extremely difficult. Baptised natives may never again get close to a church if they do not wish it and nobody is able to compel them.

What are the possible ways of coping with these problems? There are two basic approaches that may be implemented: either the enlighteners follow nomads on their routes, and this strategy becomes mimicry and leads to those people becoming nomads themselves ${ }^{1}$; or they force nomads to change, give up mobile lifestyle, i.e. they sedentarise them.

Both strategies have been implemented in the North of Russia by missionaries as well as by the Soviets. There are yet some significant differences between the two.

\section{BECOMING NOMADS}

\section{The Christian missionaries}

Both Orthodox and Protestant missionaries, in the 19th century and nowadays, share a general approach: they must go to seek at the edge of the world the last pagans. They must go to them, in order to bring them the Christian faith. Although this ideology is clearly implemented and proclaimed by the Protestant missionaries, especially in the fundamentalist protestant groups that consider missionary work as the core of their task (e.g., Vallikivi 2005, 69), and nowadays the Orthodox Church is not active in missionary work, still 
the Orthodox Church in the 18th and 19th centuries organised missionary expeditions. $^{2}$

The first that deserve to be mentioned are Filofei Leshchinskii's ${ }^{3}$ expeditions (1704-1728). He was sent to Siberia to implement Peter the Great's policy of eliminating Russia's paganism, a stain on the image of the modern Russia he intended to build (Istoriia II 1968: 324; Forsyth 1992: 154). Actually, Filofei worked to convert to Christianity the Western Siberian aborigines, who were not fully nomadic, but who dwelt deep in the taiga. In order to find them, he had to organise expeditions and to sail along rivers, in quest of the Khanty's and the Mansi's camps (Vanuyto 1994: 101). So they compelled the missionaries who wanted to reach them to move in a systematic way, because of the immensity of the territory and their great isolation. ${ }^{4}$ The Northernmost natives opposed most fiercely conversion to Christianity and they resisted attempts made by the missionary to preach in their lands: Filofei was not allowed to reach the nomad Nenets' territory and his boat was blocked before he could land (Kratkii ocherk 1892: 28; Irinarkh 1905b: 22).

The following experience of mass conversion concerns the European Nenets, whose evangelisation was achieved quite successfully by Ivan Smirnov, named Veniamin as a priest, who spent most of the time between 1825 and 1830 travelling in the Western tundras in search of Nenets groups to proselytise. He spent five years in the tundra and nearby settlements. ${ }^{5}$ Actually he was not really moving all the time, but during these five years he was pretty often on the move, living like a native, with a reindeer herd (for transportation) and a conic tent. He even had a mobile Church erected whenever the need was felt, a device that would be imitated later by the Siberian mission (Mavliutova 2001: 78-79). When Veniamin was not in the tundra, he did not have a mission headquarters to turn to, he just dwelt in the small town of Mezen, probably in the house of a merchant. This is an interesting example of mimicry: although Veniamin was not able to spend all the time of his mission in the tundra, he still adopted, in order to reach the people he wanted to convince, the same kind of lifestyle and ways of moving. He is the only one of the missionaries to have chosen this uncomfortable strategy and it certainly explains his massive success.

Roughly after the end of Veniamin's expedition, a mission was founded in the fair town of Obdorsk $\mathbf{~}^{\mathbf{6}}$. With some early interruptions, it functioned until the Revolution and we have pretty good documentation about it, especially a detailed "History of the Obdorsk mission" by the last head of the mission, Ivan Shemanovskii, called by his Orthodox name Irinarkh (Irinarkh 1906). The existence of headquarters "sedentarised" missionary work. Still, working with semi-nomadic or fully nomadic peoples required movement. So part of the 
missionaries' duty was to go out of the mission and to spend most of the time travelling. The Obdorsk missionaries more or less happily fulfilled these obligations - some of them, who do not leave for expeditions, do not remain long. Actually, to be a missionary in the conditions of the Russian North was very demanding indeed: life conditions were really poor. Life at the bases was very confined, three missionaries were living together; often, as the "History" reveals, they did not get along well. They had to travel in a harsh natural environment, defying the cold in winter and the mosquitoes in summer, to bring the Gospel to people whose language most of them did not understand, and whose behaviour was strange and unpredictable, sometimes even hostile. Although they would have liked to be independent, the missionaries needed the natives' assistance to move around. They even bought in 1857 a small herd, which later caused lots of problems to the mission, for the missionaries were not able to manage it (Irinarkh 1905h: 306; 1905m: 156-157; 1905n: 86). At the beginning of the 20 th century, while the mission develops, the expeditions do not completely cease; we have interesting accounts of tundra travels by Irinarkh, but the mission is more and more the place where the missionaries are to be found, and where they are visited by those natives who wish to keep in touch with them.

The Obdorsk mission tried to develop schools and to spread Christianity through education. Actually the school was at the beginning, in 1856, a private initiative of one missionary, Petr Popov, who maintained it by his own means (Mavliutova 2001: 87-88). Only later, in 1882, it became officially under the supervision of the mission (idem: 89). But the missionaries, in general, were not very inventive in their attempt to create schools. Schools for native children were fully stationary, nearby missions, monasteries or churches. One early school for the natives was even opened in Tyumen, very far from the Khanty regions: of the 15 boys that were recruited, several died and the few that persisted remained stuck between the two worlds: "Living far from their parents, from their families, from their region, they forgot their country and lost all contact with their people; but they were not able to assimilate into Russian society and they found themselves deprived of any ethical support, so important for young people; they fell into alcoholism and died, driving apart more and more the Natives from school and written culture" (Irinarkh 1905q: 328). Thus one of the school's goals was to uproot the children from their parents' way of life. It is not surprising that parents were not keen on sending their children to school. This was the main problem missionaries had to deal with. Irinarkh ${ }^{7}$, at the beginning of the 20 th century, was perfectly aware of the problem. He was even surprised some parents accepted separation from their children. One has the impression, while reading his texts, that he sympa- 
thises with the Nenets who do not want to give their children to school, because they love them, and that he approves of them more than of the Komi, who are eager to have their children educated into the Russian world (Irinarkh 1905g: 251; Irinarkh 1905u: 293). Therefore Irinarkh envisaged developing nomadic schools and even attempted to put his project into practice, but was hindered by several practical problems, like the cost of a herd and the lack of proper teachers (Irinarkh 1904: 300-301). Actually for these reasons, the native students were mostly orphans, unwanted by their kin, often brought by families that did not want to be encumbered by them ${ }^{8}$ (Irinarkh 1905u: 295).

The massive presence of Protestants is a new phenomenon in the North after the 1990s. More precisely, what is new is their expansion among the indigenous population, for in cities like Vorkuta they have long been present, even in Soviet times. But since the 1990s they have developed missionising in the wild around, and have convinced to convert to Baptism a conspicuous part of the Yamb-to Nenets group, a community of European Nenets that were never collectivised. They regularly go to the tundra to visit the believers. In the case of the Yamb-to Nenets, the movement started with one single convert, who introduced the Baptist missionaries to the community. The first conversion had been made while the person was in town, and only later it spread in the tundra (Vallikivi 2009). What is important for the missionaries enabling them to go and meet the nomads, is that they have an all-terrain vehicle (vezdehod), able to bring them "to the edge of the world".

So the missionary's approach is complex: on the one hand, the people they want to meet may move towards them, and often they do so, but they are also ready to move themselves towards the people, to seek them where they are. Although not all the men appointed as missionaries are ready to accept the hardships of life as a wanderer in the Northern nature, most of them consider it as part of their duty.

\section{The Soviets}

There are clear similarities in the approach, if not, of course, in the propositional dimension. As with the Orthodox missionaries ${ }^{9}$, the Soviet emissaries came to enlighten those who had still not received the message of the earthly paradise. So they intended to change deeply the heart and the understanding of all the people living in Russia. They intended to build up a State in which all the people, according to their understanding, are civilised and integrated into the same framework. Therefore their project is not mainly spiritual, but political. And, much more so than in the case of the Orthodox missionaries, they repre- 
sent the State and they serve it explicitly. At the same time, their personal devotion and commitment to the cause is also comparable to the missionaries': often they started from scratch, had to build schools themselves, to invent teaching methods, etc. They shared with their Christian predecessors the pioneer spirit.

In this framework, having the people they want to change moving around did not create favourable conditions for their aims: the impossibility to follow them systematically, the difficulty to control them becomes a real problem and therefore the enlighteners naturally start to try convincing them to change their habits and to drop nomadism. Therefore, from the beginning, the Soviets took full advantage of the movement towards them: they were based in towns or villages and they took hold of the nomads as they passed through the settlements.

Though there were some exceptions, such as the extensive expedition led by Vladimir Evladov (Evladov 1992) in 1927 in order to enquire about the possibility for the state of ensuring reindeer against any accident or natural catastrophe destroying the herd and to assess more widely the situation in Yamal. Evladov was a communist civil servant, who carried out his mission with great humanity and was clearly sympathetic towards the Nenets. He spent around 20 months in the Yamal tundra, travelling all over the peninsula and taking advantage of his meetings with the nomadic Nenets to explain the Soviet power and to gather information about their culture. One could argue that Evladov is also an enlightener, although his mission was as much about data collection. He endeavoured to explain the new world and to convince the Nenets that the "Red tsar" was concerned about their welfare. But this ideological work was attempted very cautiously. He had neither the means nor the will to implement anything forcibly.

As far as schools were concerned, the Soviets ultimately were not any more original than the missionaries, although they tried to reflect on the possibilities of having schools closer to the population. The discussion about boarding schools was quite fierce in the Committee of the North: Lunacharskii, the Minister of Education, was perfectly aware of the weaknesses of the system (Lunacharskii 1927): it was clear, also for early Soviets, that separation of small children from their families was not a good way of bringing up well balanced personalities. We know of one attempt of a nomadic school in the Surgut region in 1925, but the final solution adopted is, as before, the boarding school $^{10}$. 


\section{TO ELIMINATE NOMADISM}

\section{The missionaries}

Did the missionaries attempt to eliminate nomadism? They were opposed to it in principle. The official instructions are quite clear: the missionaries are supposed "not only to preach the Lord's Gospel to the natives, but also to teach them to read and write through translations and to spread a sedentary way of life, i.e. to help them make the first steps leading them to become citizens of the Russian State" (Kratkii ocherk 1892b: 17).

Still, if these were the default positions of the Orthodox Church, they were carried out by men who were closer to the realities of the nomadic world. Their positions varied. Undoubtedly, the official one represented the inner conviction of most missionaries: Russian way of life was for them the highest form of culture, which had to be spread. But they had not the means of implementing their aims and were compelled to stick to more easily achievable goals. Still there were some alternative reflections within the Church, led by individuals, some of them of considerable influence.

Nikolai Il'minskii is certainly the most remarkable of them: although he did not act directly in the North, his ideology influenced also his Northern followers. He had developed a whole ideology about native enlightenment, based upon the observation of the Tatars ${ }^{11}$. He had a whole strategy for bringing the non-Russian peoples closer to Orthodoxy and to be faithful subjects of the Tsar. The main change he wanted to achieve was in their spiritual way of being, as he was convinced that Christianity was the basis that would lead to other changes. Thus, he did not try to change the native's way of life, as many others did in pursuing their work as enlighteners, and commented himself about this issue, in the case of a missionary who complained that the natives did not want to change their way of life: "He gives too much importance to the improving of habits, to civilisation. According to him, the Amur aborigines 'are more attached to their ethnic traditions than the Buriats'. The Giliak, the Gold, etc, even after baptism, refuse to give up the norms and customs they are accustomed to from childhood. But if they are so attached to their way of life (which is by the way totally natural), why must we deprive them of it? Why make war to such a rooted, resilient obstacle? For simple people who are adepts of shamanism, the Christian teaching and cult are per se acceptable and congenial, if they do not interfere in their concrete life. But Christianity, which illuminates, ennobles and strengthens men in their hearts and spirits, in their understanding and in their disposition, leads in a way most direct and secure to their way of life's enrichment and correction." (Il'minskii 1898: 195). Although 
in this letter, Il'minskii is not referring to nomads, the point is clear and the same strategy has been used by missionaries working with Western Siberian nomads.

Irinarkh was a disciple of I'lminskii's and followed his steps in his demeanour. His approach to nomadism is interesting and unique in literature - especially if we consider Irinarkh as one of the enlighteners involved in the Northern societies. Irinarkh goes further than Il'minskii: he does not consider nomadism as proof of backwardness, but as "the only natural way of life in regions where agriculture is out of question" (Irinarkh 1904: 300). It is not right to think, as Russians often do, that nomadic life is degrading and insufferable: on the contrary, "it is neither as horrible nor as dangerous as it seems from far away" (idem: 304). No "white" man has yet in Russia gone as far as Irinarkh in respect for the traditional aboriginal way of life.

The Protestants nowadays do not object either to nomadism: it is not for them to decide, but for the Holy Spirit. Still, they are convinced that when the essential is obtained, the rest, including the settled way of life, will automatically follow and does not deserve particular human endeavours (Vallikivi 2009). Thus, the Protestant missionaries are on positions that seem externally quite similar to Il'minskii's. At least as far as priorities are concerned, they both focus on the spiritual. The difference is in the agency: for the Baptists, the Holy Spirit is the sole force in question, while for Il'minskii the process is a "natural" one and no special interference is needed.

\section{The Soviets}

The Soviet enlighteners wanted both to change the people's worldview and their way of life. They start from a point of view that is very similar to the Church's, but the difference is in the means involved: the Soviet enlighteners' ideology correspond to the State's and it expresses the Soviet State's fundamental ambition, which encompasses the whole of the country and inspires all other aims.

\section{The goal: to fight against backwardness}

The people concerned are considered to be at the most primitive stage of human evolution. The evolutionary scheme dominates the Soviet way of thinking. The natives are primitive people, who have skipped the capitalist phase and benefit directly from the goods of socialism. A whole theory is developed in the Soviet times in order to justify the existence of these backward people in 
the Soviet society ${ }^{12}$. But this was only acceptable if it was combined with an attempt to get rid of their primitive ways, of their uncomfortable way of life that was not fit for a Socialist state, guided by progress.

\section{The method: how to get rid of it?}

There were different ways, which were all attempted at some phase:

- Demonstration. The aim was to show the indigenous communities that "civilisation" is better than their "primitive" life. The Soviet enlighteners, led by the Committee of the North and its ideology, tried to implement this point through the "kultbasy", the cultural bases, which were, among other functions, to show the achievements of the regime and the comforts of modern life. For example, in the areas where the missionaries had worked some decades earlier, they built the Kazym cultural base, a huge complex of buildings including a school, a medical point, veterinarian services, a hostel, a "house of the native" with books and press, etc. (Leete 2002: 44-53). Actually, the results were not as encouraging as expected: in the concrete case of the Kazym cultural base, the local communities felt mostly provoked and entered into a rebellious process (Leete 2002). Usually, the Soviets did not adopt a mobile way of life, but they delved deep into the indigenous habitat and adapted themselves in crucial points. There are of course examples of Komsomol activists, who learned the vernacular languages and lived very close to the local people. Still, those enlighteners usually did not become nomadic: they were fixed in villages and thus their action could have a wider impact on the semi-nomadic or sedentary communities. A good example are the Prokofievs, a couple that started teaching in 1925 in Ianov Stan, on the Turukhan river. The husband learned Nenets (he later became one of the first specialists in Nenets and even wrote a textbook for adults (Prokofiev 1936)), and the wife learned Selkup. Both taught in the vernacular languages, but they are not known to have become nomadic (Alekseenko 1971: 295).

- Constraint. If demonstration and education was the method that corresponded best to the understandings of the Committee of North, constraint becomes the State's policy, in a later period, corresponding to the collectivisation process. Collectivisation, in the North as well as elsewhere, was mainly forced: while in the previous years people were encouraged to join in cooperatives, after 1931 they were compelled to give their reindeer to the collective farm or to join hunting and fishing cooperatives, and to have their life organised by the collective unit; people were forcibly taken from their camps on the riverside to be relocated into villages ${ }^{13}$. Sedentarisation becomes one of the key notions of 
the Soviet policy in the North. Different systems were tested in order to reduce the reindeer herders' need for movement, and some of them are still used nowadays. While the enlighteners were the main implementers of the first strategy, they are not the central instrument of this one, although many of them were more or less connected with the State institutions and helped to achieve many of the goals, as civil servants (for example Evladov).

- Education. Education is a keyword throughout all the periods of Soviet policy. Children are more easily convinced than adults, and natives might be brought to civilisation through schooling. It was easier to change children and to alienate them from the ways of their parents. Education is really the main point in Soviet strategy: it permits to achieve both

o learning "civilisation": washing, wearing underwear, eating vegetables, sleeping in a bed, in other words learning to become Russians;

o and, even more effective, "unlearning" nomadic life, and forming young people who are unable to follow their fathers' and forefathers' path, who lack the necessary skills to rely on hunting, fishing and reindeer herding (cf. Yuri Vella's positions about school, expressed for example in Niglas 2003).

The result is most satisfactory from the Soviet point of view: it is very well expressed by Anna Nerkagi in her story "Aniko from the Nokho clan" (1977). It is the story of a Nenets girl who had studied at the Institute of the Peoples of the North in Leningrad. She dreams of coming back to the tundra. But when she goes back after graduating, she is disappointed: she discovers that she is not able to live in the tundra anymore, that she misses the way of life she has become used to, that she cannot stand her father's smell. And she starts to dream of her "Russian" life... This story is very characteristic of the natives' experience, of the life of those who have undergone the school system and lost many dimensions of their identity. Still a recent analysis leads to different conclusions: Liarskaia asserts, that boarding schools have become a channel to transmit adaptation tools to children towards the double world they shall have to move in (Liarskaia 2003: 284-286). Still, this seems to be a rejoicing development of the late period: she emphasises the variety of strategies throughout the life span of the Soviet Union (ibidem). Nerkagi's story (which is more or less autobiographical) represents thus a previous period. 


\section{The situation nowadays}

Still: nomadic life has not disappeared. It is very much rooted in the Northern natives' psychology. Also, the historically evolved patterns of subsistence and relations with the authorities have created considerable regional differences. For instance, in Yamal boys coming from boarding schools and even from universities still choose to nomadise with their reindeer. When asking them why, there are several answers, but the main are: "we have the reindeer" and "we are free: we are our own bosses"14. Moreover, as Liarskaia observes, "in last times, the Nenets' cultures status has started to change, and respect towards it from the outsiders has slightly grown (Liarskaia 2003: 286).

On the other hand many children of the Northern natives have abandoned the nomadic life for good. They have become settled and they are not able to rely on themselves in nature anymore. From this point of view, the survival of nomadism is nowadays confronted with a serious gender problem. Males seem to be more attracted by life in the wild than females. It seems that girls have been more receptive than boys towards the comforts of civilisation, creating serious problems for young herders who are in need of wives ready to share their lives ${ }^{15}$.

Moreover, it would be interesting to analyse on a scientific basis the behaviour of former nomads in their stationary locations ${ }^{\mathbf{1 6}}$.

\section{CONCLUSION}

Although the changes the missionaries wanted to bring about were very fundamental, they did not actually interfere with the forms of everyday life, mainly because they lacked the means of transforming the reality around them. They had no choice but to adapt themselves, to sacrifice their own way of life and they changed themselves. We cannot say they became natives, but they attempted to meet the natives somewhere in between their areas.

The Soviets are globally less ready to find a compromise. They made no compromise; they were required to be met on their own terms and they were able to impose them, in spite of their permanent assertion that all their policies were for the accomplishment of the native's desires. One may still wonder whether the difference between them is not actually merely a question of time and means. Each of the examined groups of "enlighteners" acted within their range of possibilities and their priorities. The Soviets arrived in a historical period that inherited much of the past: in the previous centuries, missionaries (as well as merchants and civil servants) had woven a network of contacts that 
had brought Northern Siberian natives closer to the Russian world. Missionaries, who were the ones that wanted to bring about a fundamental change in their way of being, were not able to achieve capital transformations, but they were the ones who went to look for the natives in their natural environment, adopting their own principle of movement. Later, the Soviets took all the benefit of this preliminary work and could take advantage of the habits the nomads had developed of passing through towns and villages visiting their acquaintances and bartering products. Thus, they could avoid imitating their permanent movement and choose to take posts in crucial points of their routes in order to bring them towards the new order.

\section{NOTES}

1 Actually missionaries are usually fairly mobile: they go to see for proselytes where they are. Still, we cannot call them "nomads": they usually have a pretty solid base to come back to. Movement is a "professional" obligation, but not a chosed lifestyle. It is easy to move towards fixed points, but most unbalancing to move towards movement itself.

2 The political aspect of these expeditions has been emphasised by researchers. It is not my goal here to discuss the part of the political and of the religious dimensions in missionary work.

3 About Filofei's expedition, we have direct data from Novitskii (1973); other, later commentators, Abramov 1846, 1854 and 1854a, Nosilov 1898; in more recent times Vanuyto 1994.

${ }^{4}$ One must be careful when talking about isolation in Siberia: the isolation of Siberian aborigines was only relative. They had direct or indirect contacts with merchants and most of them attended fairs. They could also travel to visit neighbours. But their network of relations with the Russian world consisted of occasional points (e.g. Ventsel 2005: Chapter 1).

5 The main sources about Veniamin's expedition are his own writings: besides one scientific article (Veniamin 1855) about the European Nenets' culture, he published a kind of diary he held for its ecclesiastical authorities (Veniamin 1850, 1851). These two substantial articles are most precious for understanding Veniamin's enterprise, although they have been less used than it could be expected in Russian specialised literature.

6 In 1832-33 Makari attempted to systematise missionary work. He did not go very far from Obdorsk and was able to baptise some Khanty and Nenets who were themselves looking for baptism, but he was dispirited by native resistance and from the obstacles connected with unknown languages (I zdes' 2003: 60-61; Mavliutova 2001: 49-50). The mission was closed in 1833 and reopened only in 1854 .

7 For more details about Irinarh's personality, see Toulouze 2005; a collection of his works has been published recently (Shemanovskii 2005, 2011). 
8 This is actually the reason why Irinarkh was compelled to open in 1901 also a nursery for small children, usually orphans abandoned by their kin.

9 The term "red missionaries" has been widely used to define the persons who were sent into the North to develop education and the faith towards communism in the 1920s. See, for example, Znamenski 2003: 7.

${ }^{10}$ Actually this debate still continues. Today, everybody is convinced of the unsatisfactory character of the boarding school system, but although there have been endeavours to find alternatives allowing the education of children without uprooting them, none has been widely convincing.

11 The literature about Il'minskii is considerable, from early research (Znamenskii 1892) to more recent analysis (Lallukka 1987; Geraci \& Khodarkovski 2001; Werth 2002). For a shorter but comprehensive presentation, see Toulouze 2004.

12 There is in libraries a huge amount of literature on this subject, whose interest nowadays is only of documenting this ideology that lasted at least three decades. For instance Sergeev 1955, Budarin 1968, Kisselev 1974 and many others.

${ }^{13}$ This is the starting point of a long and painful process that was not achieved until the $1950 \mathrm{~s}$, not without many difficulties from the point of view of the state.

${ }^{14}$ Look at Liivo Niglas' film "The brigade" (2000), in which a reindeer herder, who has studied for a couple of years at Tiumen University, explains his choice exactly in these terms.

15 These points have been superbly developed by Vitebsky \& Wolfe (2001). Although their material is far from Western Siberia, the processes commented on are pretty much the same. Still, there is the Yamal exception to be noted. While my fieldwork data from the Forest Nenets and life in the taiga confirm Vitebsky's assumption, Liarskaia discovers that the Yamal does not present such features of gender shift (Liarskaya 2010).

${ }^{16}$ It seems to me intuitively, on the bases of my fieldwork, that the nomads' apartments are different from the sedentary people: much more frequently they change completely the furniture's place...

\section{BIBLIOGRAPHY}

Abramov, N. 1846. Filofei Leshchinskii mitropolit Tobol'skii i Sibirskii. Zhurnal Ministerstva narodnogo prosveshcheniia, No. 12, pp. 1-18.

Abramov, N. 1854. Propoved' Evangeliia sibirskim vogulam. Zhurnal Ministerstva narodnogo prosveshcheniia, Vol. LXXXIII, No. II, pp. 43-58.

Abramov, N. 1854a. Materialy dlia istorii khristianskogo prosveshcheniia Sibiri so vremenem pokoreniia ee $\mathrm{v} 1581$ do nachala XIX stoletiia (okonchanie). Zhurnal Ministerstva narodnogo prosveshcheniia, Vol. LXXXI, No. V, pp. 39-56.

Alekseenko, E. A. 1971. Nachal'nyi etap sovetskogo stroitel'stva na turukhanskom Severe. In: I. S. Gurvich (ed.) Osushchestulenie leninskoi natsional'noi politiki i narody Krainego Severa. Moskva: Nauka, pp. 276-298. 
Budarin, M. E. 1968. Put' malykh narodov Krainego Severa k kommunizmu (KPSS organizator sotsialisticheskikh preobrazovanii v natsional'nykh raionakh severa Zapadnoi Sibiri). Omsk: Zapadno-Sibirskoe knizhnoe izdatel'stvo.

Evladov, Vladimir P. 1992. Po tundram Iamala k Belomu ostrovu (Ekspeditsiia na Krainii Sever poluostrova Iamal v 1928-1929gg.). Tiumen': IPOS RAN.

Forsyth, James 1992. A History of the Peoples of Siberia, Russia's North-Asian Colony 1581-1990. Cambridge: Cambridge University Press.

Geraci, Robert \& Khodarkovski, Michael (eds.) 2001. Of Religion and Empire: Missions, Conversion, and Tolerance in Tsarist Russia. Ithaca: Cornell University Press.

Il'minskii, Nikolai I. 1898. Pis'ma N.I. Il'minskogo (k oberprokuroru Sviateishchego Sinoda Konstantinu Petrovichu Pobedonostsevu). Kazan'.

Irinarkh 1904 = Ieromonakh Irinarkh. K voprosu ob organizatsii shkol'nogo dela sredi kochevikov krainego severa. Pravoslavnyi vlagovestnik 1904/15, pp. 297-307.

Irinarkh $1905 \mathrm{~b}$ = Ieromonakh Irinarkh. Istoriia obdorskoi dukhovnoi missii. Pravoslavnyi vlagovestnik 1905/1, pp. 21-27.

Irinarkh $1905 \mathrm{~g}=$ Ieromonakh Irinarkh. Istoriia obdorskoi dukhovnoi missii. Pravoslavnyi blagovestnik 1905/6, pp. 248-254.

Irinarkh $1905 \mathrm{~h}=$ Ieromonakh Irinarkh. Istoriia obdorskoi dukhovnoi missii. Pravoslavnyi blagovestnik 1905/7, pp. 306-312

Irinarkh $1905 \mathrm{~m}$ = Ieromonakh Irinarkh. Istoriia obdorskoi dukhovnoi missii. Pravoslavnyi blagovestnik 1905/12, pp. 151-158.

Irinarkh $1905 \mathrm{n}$ = Ieromonakh Irinarkh. Istoriia obdorskoi dukhovnoi missii. Pravoslavnyi blagovestnik 1905/13, pp. 183-187.

Irinarkh $1905 q$ = Ieromonakh Irinarkh. Istoriia obdorskoi dukhovnoi missii. Pravoslavnyi blagovestnik 1905/16, pp. 322-328.

Irinarkh $1905 u$ = Ieromonakh Irinarkh. Istoriia obdorskoi dukhovnoi missii. Pravoslavnyi blagovestnik 1905/23, pp. 291-302.

Irinarkh 1906 = Ieromonakh Irinarkh. Istoriia obdorskoi dukhovnoi missii 1854-1904 gg. Moskva: Pechatnia A.I. Snegirevoi.

Istoriia II 1968 = Istoriia Sibiri s drevneishikh vremen do nashikh dnei. Tom II. Sibir' v sostave feodal'noi Rossii. Leningrad: Nauka.

I zdes' 2003 = I zdes' poiavliaetsia zaria khristianstva ... Obdorskaia missiia 30-e - 80e XIX $v$. Tiumen': Mandr i Ka.

Kiselev, Leonid Ekimovich 1974 = Ot patriarkhal'shchiny k sotsializmu. Opyt KPSS po sotsialisticheskomu preobrazovaniiu $v$ natsional'nykh raionakh Severa. Sverdlovsk: Sredne-Ural'skoe knizhnoe izd-vo.

Kratkii ocherk 1892 = Kratkii ocherk missionerstva v Tobol'skoi eparkhii. Pravoslavnyi vlagovestnik 1892/14, pp. 22-31.

Kratkii ocherk 1892b = Kratkii ocherk missionerstva v Tobol'skoi eparkhii. Pravoslavnyi vlagovestnik 1892/16, pp. 14-18.

Lallukka, Seppo 1987. Kazan's Teacher's Seminary and the Awakening of the Finnic Peoples of the Volga-Urals Region. Studia Slavica Finlandiensia, Vol. IV. Helsinki, pp. 143-165.

Leete, Art 2002. Kazõmi sõda. Šamanistliku kultuuri allakäik Lääne-Siberis. [Kazym War. The decline of shamanic culture in Western Siberia.] Tartu: Tartu Ülikooli Kirjastus. 
Liarskaia, Elena 2003 = Severnye internaty i transformatsiia traditsionnoi kul'tury (na primere nentsev Iamala). Sankt-Peterburg.

Liarskaya, Elena 2010. Women and the Tundra: Is There a Gender Shift on Yamal? Anthropology of East Europe Review, Vol. 28, No. 2, pp. 51-84.

Lunacharskii, A. V. 1927. Zadachi Narkomprosa na Krainem Severe. Severnaia Aziia, No. 3. Moskva.

Mavliutova, Gul'nara Shakirovna 2001. Missionerskaia deiatel'nost' russkoi pravoslavnoi tserkvi v Severo-Zapadnoi Sibiri (XIX-nachalo XX veka). Tiumen': Izdatel'stvo Tiumenskogo gosudarstvennogo universiteta.

Nerkagi, Anna 1977. Aniko iz roda Nogo. Molodaja Gvardia. Moskva.

Niglas, Liivo 2000. The Brigade (film). Documentary Educational Resourses.

Niglas, Liivo 2003. Yuri Vella's World (film). Documentary Educational Resourses.

Nosilov, K. 1898 = Kondinskii monastyr i ego missionerskaia deiatel'nost' na Severe. Pravoslavnyi blagovestnik 1898/12, pp. 164-171.

Novitskii, Grigorii 1973. Kratkoe opisanie o narode ostjackom. Studia uralo-altaica III. Szeged: Universitas Szegediensis de Attila József nominata.

Prokofiev, G. N. 1936. Samouchitel' nenetskogo iazyka. Moskva, Leningrad.

Sergeev, Mikhail Alekseevich 1955. Nekapitalisticheskii put' razvitiia malykh narodov Severa. Trudy Instituta etnografii. Novaia seriia, Vol. XXVII. Moskva, Leningrad.

Shemanovskii, Ivan Semenovich 2005. Izbrannye trudy. Compiled by L. F. Lipatova. Moskva: Izdatel'stvo "Sovetskii sport".

Shemanovskii, Ivan Semenovich 2011. Izbrannye trudy. Tom 2. Compiled by L. Lipatova. Moskva: Izdatel'stvo "Sovetskii sport".

Toulouze, Eva 2004. Mission et école dans la région de la Volga au XIX siècle: l'œuvre de Nikolaj Il’minskij. Études finno-ougriennes, N³6, pp. 7-46.

Toulouze, Eva 2005. Irinarh Shemanovskij et la mission d'Obdorsk: une page de l'évangélisation des Khantys et des Nenets. Études finno-ougriennes, №37, pp. 29-63.

Vallikivi, Laur 2005. Arktika nomaadid šamanismi ja kristluse vahel: Jamb-to neenetsite pöördumine baptismi. [Arctic nomads between shamanism and Christianity: the conversion of Yamb-to Nenets to Baptism.] Studia ethnologica et folkloristica Tartuensia 8. Tartu: Tartu Ülikooli Kirjastus.

Vallikivi, Laur 2009. Christianization of words and selves: Nenets reindeer herders joining the state through conversion. In: M. Pelkmans (ed.) Conversion After Socialism: Disruptions, Modernities and the Technologies of Faith. Oxford, New York: Berghahn Books, pp. 59-83.

Vanuyto, Valentina Iur'evna 1994. Filofei Leshchinskii. Narody Severo-zapadnoi Sibiri 1. Tomsk: Izdatel'stvo Tomskogo universiteta.

Veniamin $1850=$ Arkhimandrit Veniamin. O obrashchenii $\mathrm{v}$ khristianstvo mezenskikh samoedov v 1825-1830 godakh. Zapiski arkhimandrita Veniamina. Khristianskoe chtenie. Chast' II. Sankt-Peterburg, pp. 363-384, 410-443.

Veniamin $1851=$ Arkhimandrit Veniamin. O obrashchenii $\mathrm{v}$ khristianstvo mezenskikh samoedov v 1825-1830 godakh. God 1828. Khristianskoe chtenie. Chast' I. SanktPeterburg, pp. 64-88.

Veniamin 1855 = Arkhimandrit Veniamin. Samoedy mezenskie. Vestnik Imperatorskogo Russkogo Geograficheskogo Obshchestvo. Chast' XIV, glava II. Sankt-Peterburg, pp. $77-136$. 
Ventsel, Aimar 2005. Reindeer, Rodina and Reciprocity: Kinship and Property Relations in a Siberian Village. Halle Studies in the Anthropology of Eurasia 7. Berlin: LIT Verlag.

Vitebsky, Piers \& Wolfe, Sally 2001. The Separation of the Sexes Among Siberian Reindeer Herders. In: A. Low \& S. Tremaine (eds.) Women as Sacred Custodians of the Earth? Women, Spirituality and the Environment. New York, Oxford: Berghahn Books, pp. 81-94.

Werth, Paul William 2002. At the Margins of Orthodoxy: Mission, Governance, and Confessional Politics in Russia's Volga-Kama Region, 1827-1905. Ithaca: Cornell University Press.

Znamenski Andrei A. 2003. Shamanism in Siberia: Russian Records of indigenous spirituality. Dordrecht: Kluwer Academic Publishers.

Znamenskii, Petr 1892. Na pamiat' Nikolae Ivanoviche Il'minskom, Kazan'. 